\title{
Flumazenil improves cognitive and neuromotor emergence and attenuates shivering after halothane-, enflurane- and isoflurane-based anesthesia
}

[Le flumazénil améliore le retour de l'activité cognitive et neuromotrice et atténue les frissons après une anesthésie à base d'halothane, d'enflurane ou d'isoflurane]

Avi A. Weinbroum MD, Eran Geller MD

Purpose: To conduct a randomized, placebo-controlled, doubleblinded, clinical experiment testing the hypothesis that flumazenil, benzodiazepine antagonist, may affect recovery from halothane-, enflurane- and isoflurane-based anesthesia.

Method: Patients who underwent surgery under $\mathrm{N}_{2} \mathrm{O} / \mathrm{O}_{2}$ plus halothane $(n=100)$, enflurane $(n=100)$ or isoflurane $(n=70)$ anesthesia were administered flumazenil I mg or placebo upon emergence from anesthesia, and their postanesthesia vital signs, vigilance, neurological recovery, shivering, amnesia reversal, and general subjective feeling were assessed.

Results: A ten-point vigilance score showed better recovery of flumazenil-treated patients compared to those who received placebo (60-min after halothane anesthesia: $9.9 \pm 0.1$ vs $9.5 \pm 0.2 . P$ $<0.01$; after enflurane: $10 \pm 0$ vs $9.4 \pm 0.2, P<0.01$; after isoflurane: $\mid 0.0 \pm 0$ vs $9.3 \pm 0.1, P<0.01$ ). Halothane- and enfluraneflumazenil-treated patients (but not isoflurane) reached a better neurological score $(2.97 \pm 0.05$ or $3 \pm 0)$ compared to placebo ( 2.8 \pm 0.4 or $2.6 \pm 0.4, P<0.01$ ), respectively. Reversal of amnesia was superior in the flumazenil group at $60 \mathrm{~min}$ and at $24 \mathrm{hr}$ postsurgery, and more flumazenil patients rated recovery as "pleasant". Flumazenil patients shivered less than placebo patients despite their lower core temperature (at 30 min: halothane: I I\% vs $28 \%, P<0.05$; enflurane: $11 \%$ vs $30 \%, P<0.05$; isoflurane: $17 \%$ for both groups).

Conclusion: Flumazenil improves recovery of high cortical and neuromotor functions following halothane, enflurane and isoflurane anesthesia, reduces shivering and improves the overall quality of emergence, including patients' subjective feeling.
Objectif : Réaliser une expérience clinique randomisée, contrôlée contre placebo en double insu, testant l'hypothèse selon laquelle le flumazénil, antagoniste des benzodiazépines, peut agir sur le retour à la conscience après une anesthésie à l'halothane, à l'enflurane ou à l'isoflurane.

Méthode : Les patients devant subir une intervention sous anesthésie avec du $\mathrm{N}_{2} \mathrm{O} / \mathrm{O}_{2}$ et de l'halothane $(n=100)$, de l'enflurane $(n=$ 100) ou de l'isoflurane $(n=70)$ ont reçu I mg de flumazénil ou un placebo au réveil. Les signes vitaux, la vigilance, la récupération neurologique, les frissons, le renversement de l'amnésie et les perceptions objectives générales ont été notés.

Résultats : Une cotation de la vigilance en dix points a montré une meilleure récupération des patients traités avec le flumazénil qu'avec le placebo (60 min après l'anesthésie à l'halothane: $9,9 \pm 0,1$ vs 9,5 $\pm 0,2, P<001$; après l'enflurane : $10 \pm 0$ vs $9,4 \pm 0,2, P<0,01$; après l'isoflurane: $10,0 \pm 0$ vs 9,3 $\pm 0,1, P<0,01$ ). Avec l'halothane, ou l'enflurane (mais non l'isoflurane), combiné au flumazénil, le score neurologique a été meilleur (2,97 $\pm 0,05$ ou $3 \pm$ 0) comparé à celui du placebo $(2,8 \pm 0,4$ ou $2,6 \pm 0,4, P<0,01)$, respectivement. Le renversement de l'amnésie postopératoire a été supérieur avec le flumazénil à 60 min et à $24 \mathrm{~h}$. Un plus grand nombre de patients traités avec le flumazénil a qualifié le réveil " $d$ 'agréable". Il y a eu moins de frissons avec le flumazénil qu'avec le placebo, malgré la température centrale plus basse (à $30 \mathrm{~min}$ halothane : I I \% vs $28 \%, P<0,05$; enflurane : I I \% vs $30 \%, P$ $<0,05$; isoflurane: $17 \%$ pour les deux groupes).

Conclusion : Le flumazénil améliore la récupération des fonctions cognitives et neuromotrices à la suite d'une anesthésie avec halothane, enflurane ou isoflurane. II réduit les frissons et améliore la qualité du réveil, y compris les perceptions subjectives des patients.

From the Post-Anesthesia Care Unit and the Department of Anesthesiology and Critical Care, Tel Aviv Sourasky Medical Center and the Sackler Faculty of Medicine, Tel Aviv University, Tel Aviv, Israel.

Address correspondence to: Dr. Avi A. Weinbroum, Director, Post-Anesthesia Care Unit, Tel Aviv Sourasky Medical Center, 6 Weizman

St. Tel-Aviv 64239, Israel. Phone: +972-3-6973237; Fax: +972-3-6925749; E-mail: draviw@tasmc.health.gov.il

Accepted for publication May 14, 2001.

Revision accepted August 1, 2001. 
$\mathrm{R}$

ECOVERY from anesthesia induced with inhalation agents, especially halothane, can be distressing because of prolonged uncontrollable shivering, prolonged sedation and amnesia. ${ }^{1,2}$ The inability to normally elicit neurological reflexes, such as hyperreflexia, Achilles tendon clonus and the Babinski reflex, can also persist long after cessation of the anesthetic administration.

Compelling evidence has emerged during the years 1980-90, which indicated anesthetic action at the $\gamma$ aminobutyric acid (GABA) receptor and its chloride channel complex. ${ }^{3}$ Halothane was proved capable of enhancing pre- and postsynaptic inhibition invoked by GABA in rats ${ }^{4}$ and of potentiating GABA binding in animals. ${ }^{5}$ Halothane, isoflurane and enflurane were also shown to inhibit the breakdown of GABA and prolong GABA postsynaptic current in rats. ${ }^{6-8}$

The benzodiazepine (BZD) receptor, which is the site of action of BZD agonists, antagonists (e.g., flumazenil) and inverse agonists (e.g., ß-carbolines) is an integral part of the GABA receptor. Data has shown that BZD antagonist and partial agonists enhance the recovery of animals from inhalation anesthetics. ${ }^{9-12}$ Based on these and on our preliminary animal and human study, ${ }^{13}$ where we had demonstrated an increase in motor activity in flumazenil-treated mice that had been anesthetized with halothane compared to flumazenil-treated animals that had not undergone anesthesia, and that patients anesthetized with halothane $0.5-1.5 \%$ MAC recovered their motor and cognitive capacities faster if flumazenil was administered after anesthesia compared to individuals receiving placebo, we hypothesized that flumazenil can impinge on the recovery from anesthesia by the three mentioned inhalation anesthetics in humans, possibly by hastening the process of emergence, and/or by reducing the rate or severity of the accompanying untoward phenomena. Flumazenil, the only clinically used BZD antagonist, displays a pronounced antagonism towards and specific affinity for the central $\mathrm{BZD}$ receptor to a much higher degree than that of the known BZD agonists. ${ }^{14,15} \mathrm{We}$ investigated the effect of flumazenil on halothane, enflurane and isoflurane because these specific agents had been used in earlier studies on GABA macromolecule in the brain of primates.

\section{Methods}

\section{Patients}

The approval of the Institutional Human Studies Committee was given for the study, and signed written informed consent was obtained from all participating patients.
Three identical, consecutive and time-separated studies were conducted following a preliminary study. ${ }^{13}$ ASA I-III patients who were scheduled to undergo inguinal hernioplasty, breast biopsy or diagnostic arthroscopy under general anesthesia with nitrous oxide/oxygen and one of the three selected inhalation agents were randomly enrolled in each of the study sets. Exclusion criteria included BZD ingestion within two weeks before the study, chronic BZD use, significant cardiovascular or respiratory diseases, pregnancy, age less than $18 \mathrm{yr}$, and previous administration of inhalation agents. Preoperative blood samples were obtained from all patients for the detection of unreported BZD ingestion. Data from patients who required the administration of opiates during the first hour after surgery were excluded from the time of the injection onward.

\section{Study protocol}

Morphine sulphate $0.1 \mathrm{mg} \cdot \mathrm{kg}^{-1}$ was administered intramuscularly one hour before surgery. Anesthesia was induced with an $i v$ sleeping dose of sodium thiopentone (2 $\mathrm{mg} \cdot \mathrm{kg}^{-1}$ ) and spontaneous ventilation was maintained with $50 \% \mathrm{~N}_{2} \mathrm{O}$ (inspired concentration) in oxygen enriched with one of the three study inhalation anesthetics: $0.75 \%$ inspiratory concentration of halothane, $1.7 \%$ enflurane and $1.2 \%$ isoflurane delivered via a face mask and a semi-closed circuit. Cardio-respiratory monitoring consisted of electrocardiography, automatic oscillometric cuff blood pressure, side-stream capnography and finger plethysmography-based oxymetry (Cardiocap ${ }^{\mathrm{TM}}$, Datex ${ }^{\circledR}$, Helsinki, Finland). Core rectal temperature was also monitored. These measurements and the data concerning the anesthetic agents were continually recorded throughout the surgery and study periods by the same two protocol-blinded anesthesiologists (one in the OR, one in the postanesthesia care unit $[\mathrm{PACU}])$. No additional drugs whatsoever were administered.

Inhalation anesthetics and $\mathrm{N}_{2} \mathrm{O}$ were discontinued upon placement of the last skin suture and the patients were allowed to breathe $100 \%$ oxygen. A coded ampoule containing either $1.0 \mathrm{mg}$ flumazenil (Hoffmann La Roche, Basle, Switzerland) or an equal volume $(10 \mathrm{~mL})$ of saline was administered at a rate of $2 \mathrm{~mL} \cdot 10 \mathrm{sec}^{-1}$ when the patient began to awaken. We had shown previously, ${ }^{13,16}$ that $1 \mathrm{mg}$ flumazenil was better than 0.5 but of equal efficacy to $1.5 \mathrm{mg}$. Moreover, $1 \mathrm{mg}$ flumazenil is well reported as being the most frequent maximal dose used to reverse BZD effects in humans. ${ }^{15}$ The anesthesiologist blinded to study protocol established awakening when there was an abrupt decline in the amplitude of the finger 
plethysmogram towards pre-anesthesia levels, indicating the typical vasoconstriction associated with awakening. ${ }^{17,18}$

\section{Patient evaluation}

The following measurements were recorded just before the injection, and at five, ten, 20, 30, 40, 50 and $60 \mathrm{~min}$ after the injection of the test drug. Vigilance was assessed by ten separate variables modified from Geller and Freye $^{13,19}$ (Table I). An appropriate response to a question scored one point and an inappropriate one was scored as zero. The grading of these variables was based also on the common observation that patients in the process of recovery from inhalation anesthesia follow a predictable pattern of regaining spontaneous motor activities and some other faculties earlier than others, and that the more cognitive and complex a function is, the later it recovers. ${ }^{1}$

Neurological recovery was evaluated by scoring three reflexes temporarily absent after inhalation anesthesia: the pupillary light reflex, the eyelash reflex and the deep tendon reflex..$^{20}$ The presence of these reflexes was graded one point each. A non-resolving disturbed neurological status $^{1}$ was established by either Achilles tendon clonus, a generalized abnormal muscle resistance to limb abduction or by the presence of an extensor plantar reflex (Babinski's sign). Their presence subtracted one point each from the maximal neurological score of 3 , however, the total neurological score was never negative. ${ }^{13}$

Postanesthesia shivering lasting longer than five minutes was recorded. To differentiate between shivering associated with low body temperature and druginduced shivering, patients were stratified into hypothermic $\left(<36^{\circ} \mathrm{C}\right.$ at any time point) or normothermic $\left(\geq 36^{\circ} \mathrm{C}\right)$ subgroups after analyzing the results.

Reversal of amnesia. At each time point (see above), the patients were shown one randomly chosen simple ink drawing (out of a set of 12), and were asked to identify it. Their recall of the $0-60 \mathrm{~min}$ drawings shown to them was assessed at the end of the study (one hour). On the day following surgery, they were asked to choose the drawings that they had been shown from among assorted distraction pictures.

Twenty-four-hour assessment. The patients were asked to rate the following when the anesthesiologist visited them $24 \mathrm{hr}$ after surgery: 1) whether they remember the process of awakening from anesthesia as being "pleasant" or "unpleasant", 2) whether they recollected their transfer to the ward and 3) if and how frequently they suffered from nausea and vomiting postoperatively. If more than $1 \mathrm{mg} \cdot \mathrm{kg}^{-1}$ im meperidine had been administered at intervals less than six hours, this excluded the patient's 24-hr data from analysis.
TABLE I Vigilance score (each successfully accomplished action $=1$ point)

Eye opening - spontaneous or upon command

Limb movements - spontaneous or upon command

Answering questions

Showing tongue on command

Coherent speech

Recall of age

Recall of date of birth

Recall of address

Recall of telephone number

Simple arithmetic $2 \times 3,12 \div 4,7+4,13-5$, etc.)

Both the one-hour study and the subsequent twohour observation periods took place in PACU, the patients being closely followed by the same blinded physician. Any abnormal occurrence was noted and treated accordingly. Patients' discharge and transfer to the ward followed the routine PACU regulations.

\section{Statistical analysis}

The Statistical Laboratory of the School of Mathematics at the Tel Aviv University performed the statistical analyses. They included analysis of variance with repeated measures (ANOVA) for parametric variables, such as physiological data. The scoring method we used for postanesthesia recovery of vigilance and neurological state is categorical, but it could be converted to an ordinal scale and summed for the purposes of statistical evaluation. The sums of these variables were considered binomial because they had a Bernoulli distribution and, based on the Central Limit Theorem and because of the groups' large sample size, the mean of a binomial variable will distribute normally, thus allowing a parametric analysis of these variables. ${ }^{21}$ The generalized Mantel-Cox (Savage) test was used to compare differences between the groups in the timing of appearance or disappearance of single symptoms. If an event never occurred or if it did not disappear throughout the study period, then this case was considered as "censored" and was evaluated as such. Categorical or non-parametric data, such as judging the emergence from anesthesia as "pleasant" or "unpleasant", were examined with the Pearson chisquare test. Data are expressed as means \pm SEM, and $P$ values of less than 0.05 were considered significant.

\section{Results}

One hundred patients were anesthetized with halothane, 100 with enflurane, and 70 with isoflurane. One patient was excluded from the halothane set because traces of BZD were detected in her blood, 
TABLE II Patient data, by experiment (mean \pm SEM)

\begin{tabular}{lllllll}
\hline & \multicolumn{2}{c}{ Halothane } & \multicolumn{2}{c}{ Enflurane } & \multicolumn{2}{c}{ Isoflurane } \\
& $\begin{array}{l}\text { Flumazenil } \\
(n=46)\end{array}$ & $\begin{array}{l}\text { Placebo } \\
(n=50)\end{array}$ & $\begin{array}{l}\text { Flumazenil } \\
(n=46)\end{array}$ & $\begin{array}{l}\text { Placebo } \\
(n=50)\end{array}$ & $\begin{array}{l}\text { Flumazenil } \\
(n=35)\end{array}$ & $\begin{array}{c}\text { Placebo } \\
(n=34)\end{array}$ \\
\hline Age (yr) & $48 \pm 2$ & $53 \pm 3$ & $46 \pm 3$ & $52 \pm 3$ & $47 \pm 3$ & $47 \pm 4$ \\
Weight $(\mathrm{kg})$ & $70 \pm 2$ & $68 \pm 2$ & $72 \pm 3$ & $66 \pm 2$ & $69 \pm 3$ & $73 \pm 2$ \\
Sex (male/female) & $36 / 16$ & $35 / 15$ & $36 / 10$ & $36 / 14$ & $25 / 10$ & $23 / 11$ \\
Thiopentone (mg) & $159 \pm 1$ & $160 \pm 1$ & $144 \pm 1$ & $154 \pm 1$ & $133 \pm 2$ & $137 \pm 1$ \\
Duration of surgery (min) & $64 \pm 3$ & $67 \pm 4$ & $65 \pm 3$ & $69 \pm 4$ & $56 \pm 4$ & $60 \pm 3$ \\
Diagnostic arthroscopy $(n)$ & 15 & 16 & 16 & 19 & 12 & 11 \\
Inguinal herniorrhaphy $(n)$ & 26 & 28 & 26 & 23 & 18 & 19 \\
Breast biopsy $(n)$ & 5 & 6 & 4 & 8 & 5 & 4 \\
I-D interval (min) & $9.1 \pm 01$. & $9.7 \pm 0.2$ & $9.0 \pm 0.2$ & $9.5 \pm 0.1$ & $5.9 \pm 0.1$ & $5.1 \pm 0.1$ \\
On-ward PONV & 8 & 7 & 9 & 7 & 6 & 8 \\
On-ward meperidine (dose/Pt) & $1.8 \pm 0.04$ & $1.7 \pm 0.05$ & $1.8 \pm 0.07$ & $1.6 \pm 0.06$ & $1.9 \pm 0.1$ & $1.8 \pm 0.1$ \\
\hline
\end{tabular}

There were no significant differences between the flumazenil and the placebo groups in the three study sets.

I-D interval=time between discontinuation of inhalation anesthetic and injection of test drug; PONV=postoperative nausea and vomiting $n=$ number of patients or events; $\mathrm{Pt}=$ patient.

and three other patients were excluded for having experienced excessive pain in PACU for which they received meperidine. Four patients were excluded in the enflurane set: three because BZD traces were found in their blood and the fourth required assisted ventilation because of upper airway obstruction. One patient was excluded in the isoflurane set after unreported BZD use was discovered.

The flumazenil and the placebo groups of patients in each of the three sets of experiments were similar and matched with respect to their demographic, surgical and anesthesia data (Table II). The time interval between disconnection of inhalation anesthetics and the moment the test drug was injected was also similar in each set (I-D interval, Table II). There were no statistical differences in heart rate, blood pressure, respiratory rate, oxygenation and end-expired carbon dioxide throughout surgery and during the postoperative study period among the three sets of experiments (data not shown).

\section{Halothane anesthesia}

Maximal vigilance scores representing the gradual recovery of mental and cognitive functions were reached earlier in the flumazenil-treated patients than in their controls (Figure 1A). The analysis of variance that was applied to these cumulative scores showed a statistically significant difference in the recovery from halothane anesthesia between the two groups at different times $(\mathrm{F}=17.8, \quad P<0.01$ for the interaction between time and group). Evaluation of individual vigilance parameters also revealed faster complete recovery in the flumazenil group: all flumazenil-treat- ed patients moved their limbs spontaneously at 40 min, compared to $92 \%$ of the placebo patients at the 60 -min time point $(P<0.01)$, and the capability to do simple arithmetic calculations (see specification Table I) also was regained faster among the flumazenil-treated patients (Figure 1B)

Neurological scores in the flumazenil-treated patients were significantly higher $(\mathrm{F}=12.6, P<0.01)$ and best restoration of normal neurological status was achieved earlier $(P=0.04)$ in more flumazenil patients than placebo patients (Figure 2). Mantel-Cox analysis of the individual neurological variables showed that resistance to knee abduction obtained by the blinded physician was achieved in all flumazenil-treated patients at $30 \mathrm{~min}$ compared to $93 \%$ in the placebo patients $(P=0.03)$. Thirty minutes after drug injection, the patellar reflex was re-established in all flumazenil patients compared to $35 \%$ of the placebo patients ( $P$ $<0.01)$. Achilles tendon clonus was last observed ten minutes after drug injection in three flumazenil patients compared to 12 control patients $(P=0.02)$; at $30 \mathrm{~min}$, the clonus was not obtainable in any flumazenil-treated patient but was still detected in nine placebo-treated ones $(P<0.01)$.

Shivering occurred less frequently in the flumazenil group (30 min, five patients) than in the placebo group ( $30 \mathrm{~min}, 14$ patients, $P<0.05$ ) even though the mean core temperature at ten to $30 \mathrm{~min}$ in the flumazenil group was significantly $(P<0.05)$ lower than in the placebo patients (Figure 3 ). Shivering among the normothermic flumazenil patients was less frequent than among the normothermic placebo patients throughout the study period (Figure 4). 

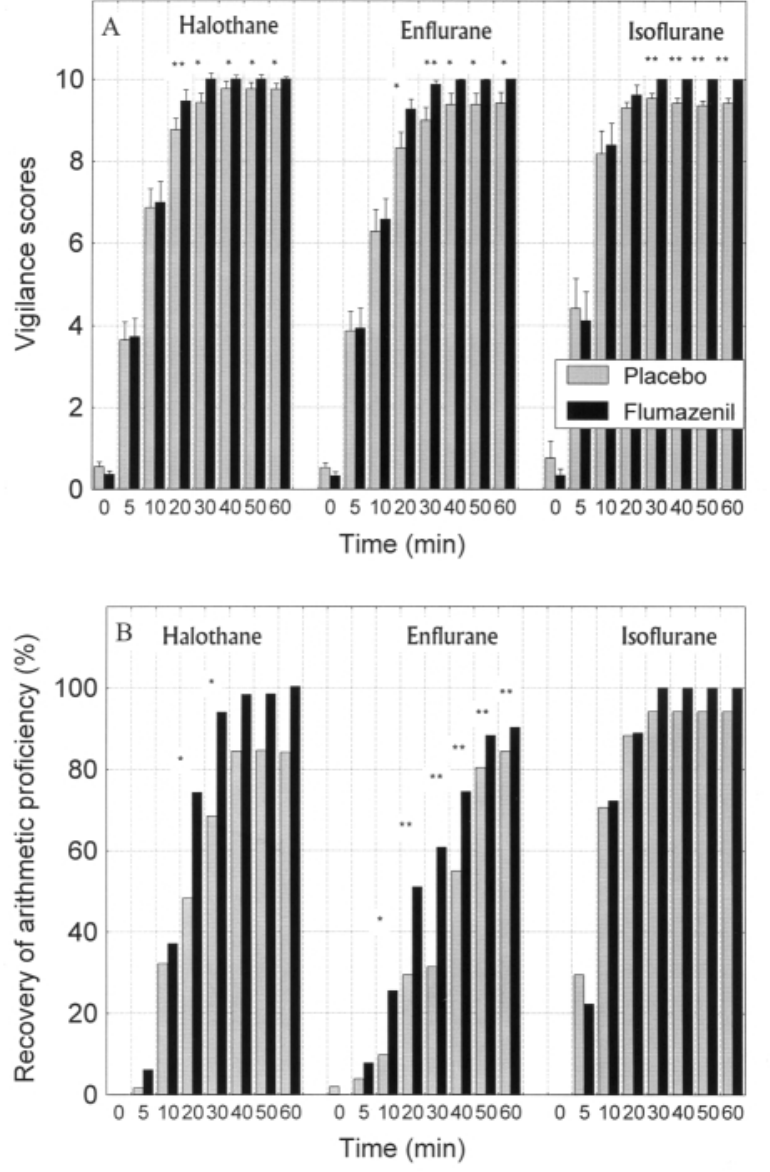

FIGURE 1 Recovery of mental functions. A, Data represent pooled vigilance parameters as specified in Table I; B, Percentage of patients in each gexp capable of performing simple arithmetic calculations. Values expressed as means \pm SEM. ${ }^{*} P<0.05,{ }^{* *} P$
$<0.01$ between flumazenil-treated patients and placebo-injected patients (planned comparisons). The first left-side asterisk indicates the time point when differences were first considered of statistical value.

There were fewer differences in the incidence of shivering in the hypothermic patients of the two groups too (Figure 4).

The time that elapsed from drug administration to the first identification of a picture was similar in both groups $(11.1 \pm 0.9 \mathrm{~min}$ in the flumazenil group and $12.7 \pm 1.1 \mathrm{~min}$ in the placebo group, $P=\mathrm{NS}$ ), as was the total number of pictures recognized (Figure 5). The one-hour and the 24-hr memory recall of pictures, as well as the recollection of being transferred to the ward were also better the flumazenil patients (Figure 5).

Although the on-ward incidence of nausea and

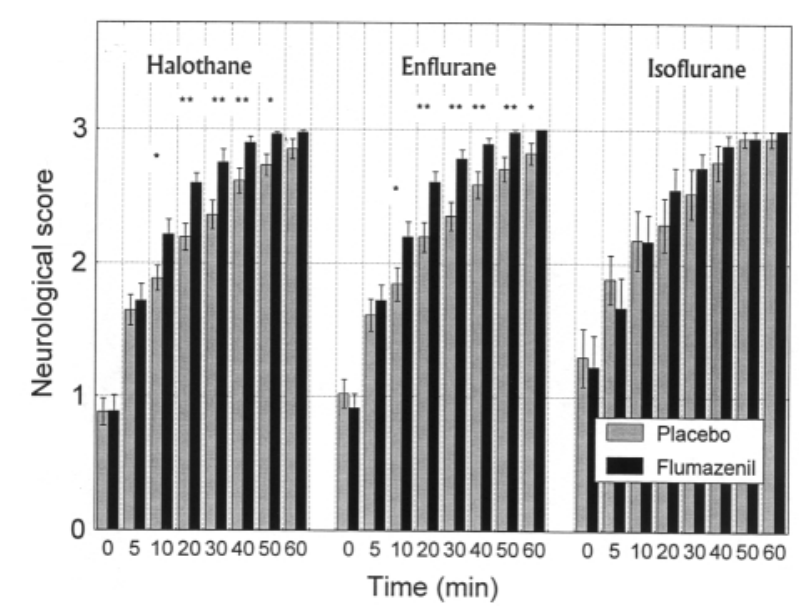

FIGURE 2 Recovery of neurological status. Values expressed as means \pm SEM. ${ }^{*} P<0.05,{ }^{*} P<0.01$ between flumazenil-treated patients and placebo-injected patients (planned comparisons). The first left-side asterisk indicates the time point when differences were first considered of statistical value.

vomiting was similar in the two groups (Table II), $80 \%$ of the flumazenil vs $46 \%$ of the control patients ( $P$ $<0.001)$ described the recovery from halothane anesthesia as "pleasant".

\section{Enflurane anesthesia}

In these two matched groups (Table II), the vigilance scores were higher (Figure 1A) and full recovery was reached earlier $(40 \mathrm{~min})$ in the flumazenil-treated patients than in the placebo patients who did not recover fully within one hour $(\mathrm{F}=16.6, P<0.01)$. The capability to do simple arithmetic calculations also recovered faster in this flumazenil group $(P<0.01$, Figure 1B).

Maximal neurological scores indicating normal neurological status in the flumazenil-treated patients were detected at $60 \mathrm{~min}$ but never in the placebo individuals. Overall, normalization was reached significantly $(\mathrm{F}=2.38, P<0.05)$ earlier and was improved by flumazenil compared to placebo (Figure 2). Twenty minutes after drug injection, resistance to knee abduction had disappeared and the patellar reflex was restored in all the flumazenil patients compared to the respective values of $30 \%$ and $55 \%$ recorded in the placebo group $(P<0.05$ and $P<0.01$, respectively $)$.

Shivering was recorded in fewer flumazenil-treated patients than in the patients who received placebo (at $30 \mathrm{~min}, 11 \%[n=5]$ vs $30 \%[n=15], P<0.05)$ even 


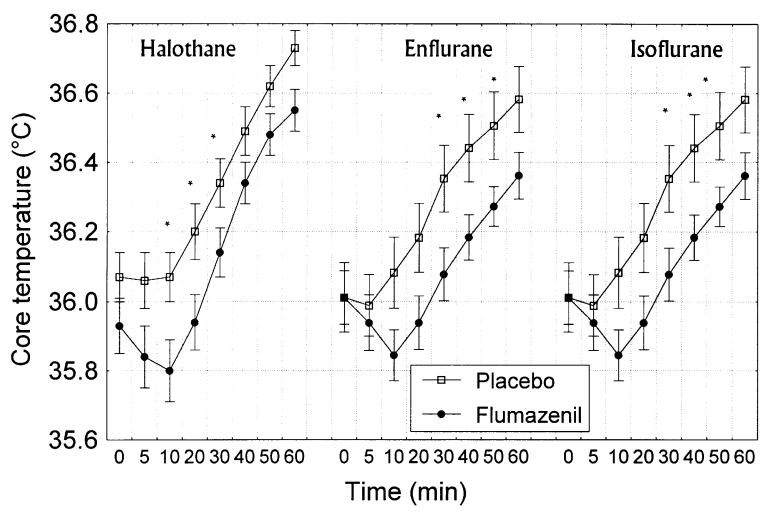

FIGURE 3 Post-anesthesia core temperature. Values expressed as means \pm SEM. ${ }^{*} P<0.05$ between flumazenil- treated patients and placebo-injected patients

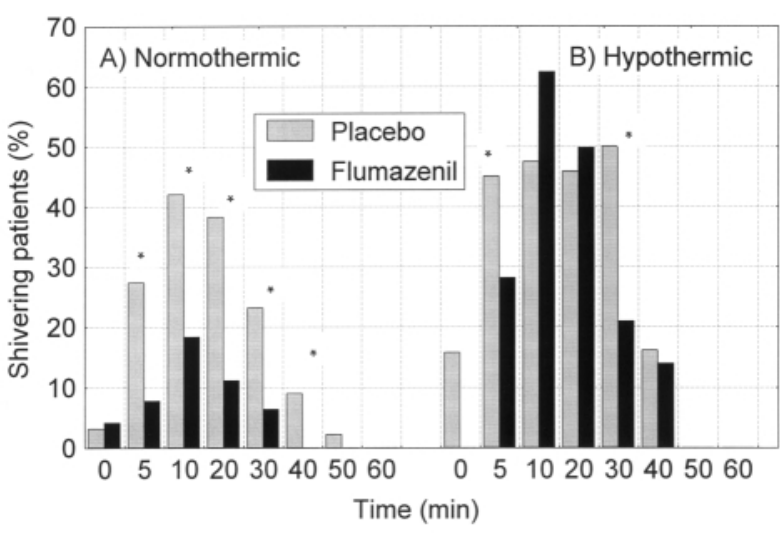

FIGURE 4 Post-halothane incidence of shivering. (A) Normothermic patients $\left(\geq 36^{\circ} \mathrm{C}\right)$; (B) Hypothermic patients $\left(<36^{\circ} \mathrm{C}\right) .{ }^{*} P<0.05$ between flumazenil-treated patients and place bo-injected patients.

though the mean core temperature in the former was statistically $(P<0.05)$ lower (Figure 3$)$.

The time that elapsed from drug administration to the first identification of a picture was similar for all enflurane patients $(12.5 \pm 1.2 \mathrm{~min}$ in the flumazenil group, $11.1 \pm 0.8 \mathrm{~min}$ in the placebo group, $P=\mathrm{NS}$ ). While the immediate recognition of pictures was similar, recall of the pictures at $60-\mathrm{min}$ and at $24-\mathrm{hr}$ postanesthesia were significantly $(P<0.01)$ better in the flumazenil than in the untreated individuals (Figure 5). Recollection of transfer to the ward, was
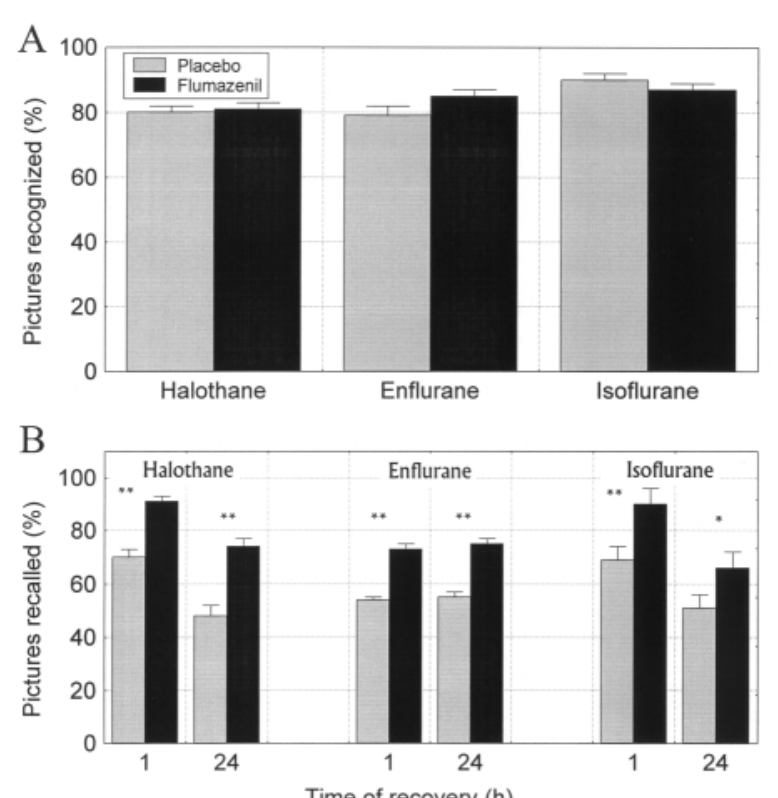

C

Time of recovery $(\mathrm{h})$

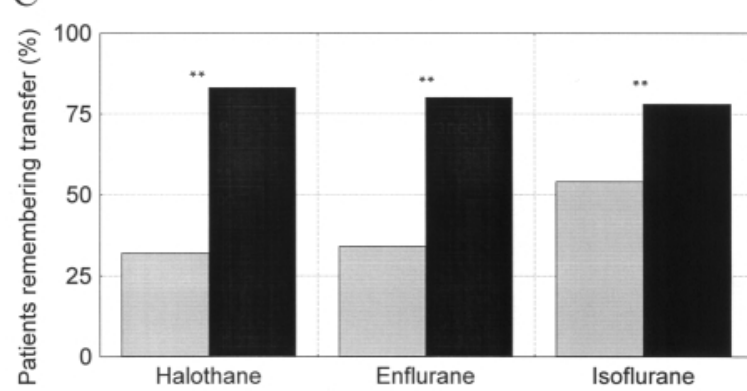

FIGURE 5 Recovery of memory function. Values expressed as means \pm SEM. (A) Percent of the pictures recognized during the one-hour study; (B) Percent of pictures recalled at the end of the one-hour study and those recollected $24 \mathrm{hr}$ after the study; (C) Percent of patients in each group who remembered their transfer from the PACU to the ward. ${ }^{*} P<0.05,{ }^{*} P<0.01$ between flumazenil-treated patients and placebo-injected patients.

also significantly $(P<0.01)$ better in the flumazenil patients (Figure 5 ).

Eighty-three percent of the flumazenil vs 38\% of the placebo patients $(P<0.01)$ described the recovery from enflurane anesthesia as "pleasant".

\section{Isoflurane anesthesia}

Following anesthesia with isoflurane, the total vigilance scores were higher (Figure lA) and full recovery was reached earlier $(30 \mathrm{~min})$ in flumazenil-treated patients than in placebo individuals (more than one 
hour, $\mathrm{F}=95.4, P<0.01)$. Nevertheless, no single vigilance parameter was different between the groups (e.g., arithmetic variable, Figure 1B), and neurological scores were also similar (Figure 2).

Despite their significantly lower mean core temperatures towards the end of the study (Figure 3 ), there was less shivering in the flumazenil patients $(5-$ and 10 -min, $n=11)$ than in the placebo patients $(n=25, P$ $<0.05)$. This difference disappeared at the $30-\mathrm{min}$ time point, when $17 \%$ of the patients in both groups were noted to still be shivering.

The time elapsed from drug administration to the time a picture was first identified was similar $(9.7 \pm 1.2$ $\mathrm{min}$ in the flumazenil group and $8.5 \pm 1.0 \mathrm{~min}$ in the placebo group, $P=\mathrm{NS}$ ), and this was associated with similar rates of picture identification thereafter. The one-hour and 24-hr memory recall tests were better in the flumazenil patients, as was the recollection of transfer to the ward (Figure 5).

All of the flumazenil-treated patients vs $32 \%$ of the controls $(P<0.01)$ rated recovery from isoflurane anesthesia as "pleasant" at the 24 -hr visit.

\section{All study sets}

The patients in all three sets of the study recovered from anesthesia and none experienced neurological or cognitive relapse up to their discharge from the PACU. All were uneventfully discharged home $24 \mathrm{hr}$ later; the incidence of postoperative nausea and vomiting (PONV) was similar in each of the three study sets, as was the mean patient dose of on-ward meperidine (Table II)

\section{Discussion}

This double-blind, placebo-controlled, three-phase study demonstrated that the specific BZD antagonist, flumazenil, enhanced the recovery of cognitive activities and improved the quality of emergence following halothane-, enflurane- and isoflurane-based anesthesia. When flumazenil was given approximately ten minutes after stopping the administration of the inhalation agents, the associated neurological and $\operatorname{cog}$ nitive depression disappeared sooner and neuromuscular activity returned to normal earlier than in the patients receiving placebo. This was especially evident after anesthesia with halothane and enflurane. Postanesthesia amnesia was more promptly and efficiently reversed with flumazenil and persisted thereafter. Importantly, the majority of the treated patients in all the experiments rated their recovery from inhalation anesthesia as "pleasant". Unexpectedly, the postanesthesia temperature-independent shivering was reduced in the flumazenil-treated patients, especially after halothane, but also after the administration of enflurane and isoflurane anesthesia.

\section{Flumazenil-anesthesia drugs interaction}

Of the three tested agents, halothane with its typical slow emergence provided the best model to discern the action of flumazenil. When enflurane or isoflurane were used instead of halothane, flumazenil bestowed the same neurological and cognitive benefits and the sparing of shivering and amnesia, but with less intensity. This is probably due to the faster recovery from anesthesia with the latter two agents, especially isoflurane, which is related to their physical and pharmacokinetic characteristics. Indeed, an overall minimal effect was observed when flumazenil was administered after sevoflurane-based anesthesia (Weinbroum, unpublished data). Intraoperatively, only short-lasting anesthetic agents (thiopentone and $\mathrm{N}_{2} \mathrm{O}$ ) were administered concurrently with the inhalation anesthetics. The clinical effects of the low dose of thiopentone administered in our study had almost certainly dissipated by the time flumazenil was administered, i.e., after more than one hour. ${ }^{22}$ It was shown that eyelid reflex was fully restored within less than five minutes following an $i v$ injection of $5 \mathrm{mg} \cdot \mathrm{kg}^{-1}$ thiopentone in humans (more than twice the dose used in the present study). ${ }^{23}$ Only few case reports have described unexplained antagonistic effects of flumazenil in cases of barbiturates-induced central nervous system depression. ${ }^{16,24}$ In-vivo and in-vitro studies have concluded that barbiturates and BZD act at two distinct and separate sites of the GABA receptor complex. ${ }^{25}$ Also, even if barbiturates might modulate GABA action to produce a pro-inhibitory effect, this would only occur when BZD are present at the binding site. That was not the case in the present study.

The effects of flumazenil in our study were apparent more than 20 min after $\mathrm{N}_{2} \mathrm{O}$ discontinuation, when $\mathrm{N}_{2} \mathrm{O}$ would have most likely been washed out of the body. We found no evidence in the literature suggesting that flumazenil produced any reversal effects on $\mathrm{N}_{2} \mathrm{O}$ in humans, except for attenuation of some $\mathrm{N}_{2} \mathrm{O}$-induced subjective effects by a very high (supraclinical, $5 \mathrm{mg}$ ) dose of flumazenil in volunteers. ${ }^{26} \mathrm{~A}$ very high dose of flumazenil that had been administered to rats, which were treated simultaneously with $\mathrm{N}_{2} \mathrm{O}$, had no effect on their intraoperative or awakening parameters. ${ }^{27}$ It can be concluded, therefore, that in the clinical setting of the current study, flumazenil must have counteracted the central effects of anesthesia by halothane, enflurane and isoflurane. 


\section{BZD and inhalation anesthetics}

The interaction of inhalation anesthetics with BZD compounds has been the subject of several previous studies. Flumazenil was shown not to affect the loss of the righting reflex during anesthesia with halothane in mice $^{9}$ or in other animals, ${ }^{28,29}$ suggesting its lack of effect on the minimal alveolar concentration (MAC) of the anesthetic. Other authors, however, found that flumazenil exerted a BZD agonist-like effect on inhalation anesthesia. ${ }^{30,31}$ Geller and coworkers ${ }^{9}$ were first to demonstrate an enhanced recovery during emergence in mice treated with flumazenil, as judged by the early resumption of motor activity. Weinger and associates reported antagonistic effects by inverse agonists of BZD on the recovery from halothane anesthesia in rats, ${ }^{10}$ and others described similar effects on recovery from methoxyflurane anesthesia in rats ${ }^{11}$ and mice. ${ }^{12}$ Such results point to a neuropharmacological interaction between inhalation anesthetics and BZD antagonists after inhalation-based anesthesia and, therefore, would support flumazenil's ability to interact with inhalation anesthetics.

The effects described herein were clinically different from those flumazenil has been shown to evoke previously, such as the rapid onset of the reversal of BZD induced CNS depression. ${ }^{15}$ This did not occur in the present study, perhaps because of the presence of residual anesthetics in the body, which prevented flumazenil from causing immediate changes in the variable tested, ${ }^{9,28,29}$ particularly in the halothane group. We therefore suppose that, had flumazenil been administered later, its effects during emergence from anesthesia might have been less significant. Moreover, since BZD and inhalation agents were shown to interact in a nonadditive agonistic fashion, ${ }^{32}$ the antagonism evoked by flumazenil may be incomplete. Complex neuropharmacological and physical factors (e.g., brain-blood partition coefficient) could thus explain the differences among the three inhalation agents following the injection of flumazenil, even though at a clinically predetermined (plethysmogram-based) common time point.

\section{Reversal of amnesia}

There were large differences between the two groups of patients within each study set in terms of one-hour and 24-hr recall of pictures and the recollection of being transferred to the ward. At the same time, the similar grade of reproduced memory detected in all the flumazenil-treated groups implies a GABA receptorrelated mechanism of action, that the inhalation anesthetics converged onto this macromolecule to produce amnesia, and that the binding of flumazenil reversed its effect. ${ }^{33}$ Noteworthy, the flumazenil-induced reacquisi- tion of memory following inhalation anesthesia differed from that obtained after the reversal of BZD-induced amnesia (where the one-hour reversal is usually followed by re-amnesia) ${ }^{15}$ possibly due to a different flumazenil-inhalation anesthetics interaction.

\section{Reduction of shivering}

The unanticipated attenuation of posthalothane shivering and, to a lesser extent, after enflurane and isoflurane, is an impressive and subjective phenomenon that was detected in this study. The lesser effect of flumazenil in the two latter sets of study could probably relate to the anesthetics' pharmacokinetic characteristics. Decreased shivering may be correlated, both temporally and neuromuscularly, to the rapid normalization of general muscle tone that was obtained with flumazenil, as documented in this study. However, reduced shivering might have also slowed the recovery of normal body heat in our patients, resulting in a lower body temperature in the flumazenil-treated patients. During recovery from inhalation agents, shivering and secondary abnormal neurological phenomena carry potentially serious implications, especially in high-risk patients. Given that the effect was consistent across all three inhalation agents, and in light of the high grade of pleasantness expressed by the treated patients, flumazenil could be of help to specific groups of patients, particularly that with cardiac risk factors. Nevertheless, flumazenil is still a drug of limited use in many parts of the world, and its relatively high price may remain an obstacle to its regular use. Wise clinical practice and individual cost-benefit consideration could help overcome objections, especially when weighing the cost of $1 \mathrm{mg}$ flumazenil (US $\$ 50.00$ in the authors' institution) with that of recovery for an additional hour in the PACU (up to \$200).

In conclusion, the present human double-blind, placebo-controlled study indicates that flumazenil improves the quality of awakening, decreases the incidence of shivering and hastens the course of recovery of cognitive and motor activities from anesthesia by halothane, enflurane and, to a lesser extent, isoflurane. The precise pharmacological mechanism(s) by which flumazenil acts and its potential clinical implications requires additional investigations.

\section{Acknowledgements}

The authors wish to thank Ms. Esther Eshkol for her invaluable editorial assistance in preparing this manuscript, Dr. Itay Bentov for his skillful help in collating the data, Ms. Ilana Gelernter for the statistical help, and the Hoffmann La Roche Co., Basle, Switzerland for generously providing the blinded ampoules. 


\section{References}

1 Rosenberg H, Clofine R, Bialik O. Neurologic changes during awakening from anesthesia. Anesthesiology 1981; 54: 125-30.

2 McCulloch PR, Milne B. Neurological phenomena during emergence from enflurane or isoflurane anaesthesia. Can J Anaesth 1990; 37: 739-42.

3 Moody EJ, Suzdak PD, Paul SM, Skolnick P. Modulation of the benzodiazepine/gamma-aminobutyric acid receptor chloride channel complex by inhalation anesthetics. J Neurochem 1988; 51: 1386-93.

4 Bishop BE, Laverty $R$. Dose-dependent reduction by Ro 15-4513 in mice of the effects of ethanol and some other general depressant drugs. Eur J Pharmacol 1989 162: 265-71

5 Cheng SC, Brunner EA. A neurochemical hypothesis for halothane anesthesia. Anesth Analg 1975; 54: 242-6.

6 Cheng SC, Brunner EA. Effects of anesthetic agents on synaptosomal GABA disposal. Anesthesiology 1981; 55: 34-40.

7 Gage PW, Robertson B. Prolongation of inhibitory postsynaptic currents by pentobarbitone, halothane and ketamine in CAl pyramidal cells in rat hippocampus. Br J Pharmacol 1985; 85: 675-81

8 Jones MV, Brooks PA, Harrison NL. Enhancement of gamma-aminobutyric acid-activated $\mathrm{Cl}^{-}$currents in cul tured rat hippocampal neurones by three volatile anaesthetics. J Physiol Lond 1992; 449: 279-93.

9 Geller E, Schiff B, Halpern P, Speiser Z, Cohen S. A benzodiazepine receptor antagonist improves emergence of mice from halothane anaesthesia. Neuropharmacology $1989 ; 28: 271-4$

10 Weinger MB, Schreiber JF, Koob GF. Effects of two benzodiazepine inverse agonists, $\mathrm{RO} 15-4513$ and FG 7142 , on recovery from pentobarbital and halothane anesthesia in the rat. Pharmacol Biochem Behav 1990 35: 889-5

11 Miller DW, Yourick DL, Tessel RE. Antagonism of methoxyflurane-induced anaesthesia in rats by benzodiazepine inverse agonists. Eur J Pharmacol 1989; 173: $1-10$.

12 Moody EJ, Skolnick P. The imidazobenzodiazepine Ro 15-4513 antagonizes methoxyflurane anaesthesia. Life Sci 1988; 43: 1269-76.

13 Geller E, Weinbrum A, Schiff B, et al. The effect of flumazenil on the process of recovery from halothane anaesthesia. Eur J Anaesthesiol 1988; Suppl 2: 151-3.

14 Hunkeler W, Mobler H, Pieri L, et al. Selective antagonists of benzodiazepines. Nature 1981; 290: 514-6.

15 Weinbroum AA, Flaishon R, Sorkine P, Szold O, Rudick $V$. A risk-benefit assessment of flumazenil in the management of benzodiazepine overdose. Drug Saf 1997; 17: $181-96$.
16 Weinbroum A, Halpern P, Geller E. The use of flumazenil in the management of acute drug poisoning-a review. Intensive Care Med 1991; 17 Suppl 1: S32-8.

17 Blanc VF, Haig M, Troli M, Sauve B. Computerized photo-plethysmography of the finger. Can J Anaesth 1993; 40: 271-8.

18 Sellgren J, Ponten J, Wallin BG. Percutaneous recording of muscle nerve sympathetic activity during propofol, nitrous oxide, and isoflurane anesthesia in humans Anesthesiology 1990; 73: 20-7.

19 Freve E, Fournell A. Postoperative reversal of loss of vigilance following midazolam with the use of the antagonist flumazenil (Ro 15-1788). A comparative study with a placebo and the use of EEG-power spectra (German). Anaesthesist 1988; 37: 162-6

20 Gillespie NA. The signs of anaesthesia. Anesth Analg Curr Res 1943; 22: 275-80.

21 Karr $A F$. Probablility. New York: Springer-Verlag Publishers, 1993: 12-4.

22 Hudson RJ, Stanski DR, Burch PG. Pharmacokinetics of methohexital and thiopental in surgical patients. Anesthesiology 1983; 59: 215-9.

23 Woerlee GM. Practical IV bolus kinetics and dynamics. In: Woerlee GM (Ed.). Kinetics and Dynamics of Intravenous Anaesthetics. The Netherlands: Kluwer Academic Publishers, 1992: 116-47.

24 Fassoulaki A, Sarantopoulos C, Papilas K. Flumazenil reduces the duration of thiopentone but not of propofol anaesthesia in humans. Can J Anaesth 1993; 40: 10-2.

25 Tanelian DL, Kosek P, Mody I, Maclver MB. The role of GABAA receptor / chloride channel complex in anesthesia. Anesthesiology 1993; 78: 757-76.

26 Zacny JP, Yajnik S, Coalson D, et al. Flumazenil may attenuate some subjective effects of nitrous oxide in humans: a preliminary report. Pharmacol Biochem Behav 1995; 51: 815-9.

27 Quock RM, Wetzel PJ, Maillefer RH, Hodges BL, Curtis $B A, C z e c h D A$. Benzodiazepine receptor-mediated behavioral effects of nitrous oxide in the rat social interaction test. Pharmacol Biochem Behav 1993; 46: 161-5.

28 Schwieger IM, Szlam F, Hug CC Jr. Absence of agonistic or antagonistic effect of flumazenil (Ro 15-1788) in dogs anesthetized with enflurane, isoflurane, or fentanyl-enflurane. Anesthesiology 1989; 70: 477-80.

29 Greiner AS, Larach DR. The effect of benzodiazepine receptor antagonism by flumazenil on the MAC of halothane in the rat. Anesthesiology 1989; 70: 644-8.

30 Schwartz AE, Maneksha FR, Kanchuger MS, Sidhu US, Poppers PJ. Flumazenil decreases the minimum alveolar concentration isoflurane in dogs. Anesthesiology 1989; 70: 764-6. 
31 Hansen TD, Warner DS, Todd MM, Baker MT, Jensen $N F$. The influence of inhalational anesthetics on in vivo and in vitro benzodiazepine receptor binding in the rat cerebral cortex. Anesthesiology 1991; 74: 97-104.

32 Schwieger IM, Hall RI, Hug CC Jr. Less than additive antinociceptive interaction between midazolam and fentanyl in enflurane-anesthetized dogs. Anesthesiology 1991; 74: 1060-6.

33 Flaishon R, Halpern P, Sorkine P, et al. Cross-sensitivity between isoflurane and diazepam: evidence from a bidirectional tolerance study in mice. Brain Res 1999; $815: 287-3$

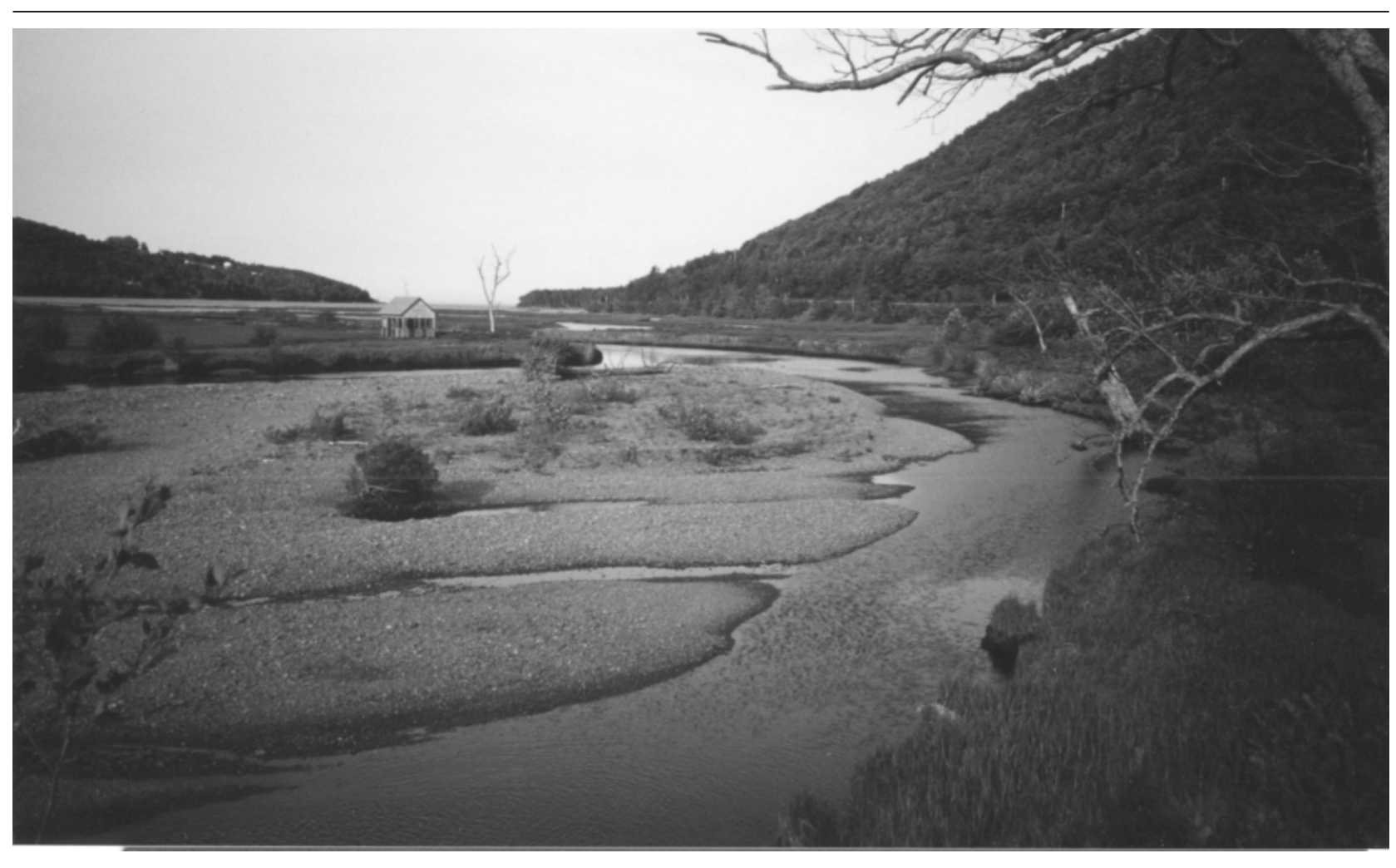

Ingonish - Nova Scotia 